JAMP: Jurnal Adminitrasi dan Manajemen Pendidikan

Volume 3 Nomor 2 Juni 2020, Hal : 118-122

Tersedia Online di http://journal2.um.ac.id/index.php/jamp/

ISSN 2615-8574 (online)

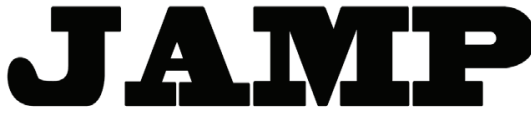

JURNAL ADMINISTRASI DAN MANAJEMEN PENDIDIKAN

\title{
BUDAYA ORGANISASI SEKOLAH DALAM MEMPERSIAPKAN SUMBER DAYA MANUSIA UNGGUL
}

\author{
Yesi Ismawati \\ Ainie Rahmah \\ Mukhlis Nur Fathi \\ Reny Jamaliyah \\ Anis Luluk Rahmadani \\ Nurul Arfinanti \\ Prodi Pendidikan Matematika Fakultas Sains dan Teknologi \\ Universitas Islam Negeri Sunan Kalijaga Yogyakarta \\ E-mail: yesiismwt@gmail.com
}

\begin{abstract}
School as an organization certainly has a culture of organization which becomes an important role in the realization of the vision and mission of school. The culture of school organizations is the norms adopted and implemented by all components to achieve the vision and mission of the school effectively. This study aims to describe the culture of school organizations in SMK Negeri 2 Depok Sleman for preparing superior human resources and programs to support the culture of school. The approach of this study was quantitative observation, interview and documentation were used as the instruments of eliciting the data. The research subjects included elements of school residents, namely the deputy headmaster, teachers, and students. The results of this observation showed that (1) SMK Negeri 2 Depok Sleman has three superior cultures namely the culture of discipline, cooperation, and the culture of industrial work, (2) there are several programs for students in the application of school culture, (3) there are supporting and inhibiting factors for the realization of an effective school organization culture. According to observations, the culture of school organizations in SMK Negeri 2 Depok Sleman can be said to be effective.
\end{abstract}

Keywords: the Culture of School Organizations, Superior Human Resources, Effective

\begin{abstract}
Abstrak: Sekolah sebagai suatu organisasi tentunya memiliki budaya organisasi yang menjadi peran penting dalam terwujudnya visi misi sekolah. Budaya organisasi sekolah merupakan norma-norma yang dianut dan dilaksanakan oleh seluruh komponen sekolah untuk mencapai visi dan misi sekolah secara efektif. Penelitian ini bertujuan untuk menggambarkan budaya organisasi sekolah yang ada di SMK Negeri 2 Depok Sleman dalam mempersiapkan sumber daya manusia yang unggul dan program-program sekolah yang untuk mendukung budaya sekolah. Metode yang digunakan dalam observasi ini adalah pendekatan kualitatif dengan teknik pengumpulan data melalui observasi, wawancara, dan dokumentasi. Subjek penelitian meliputi unsur warga sekolah, yaitu wakil kepala sekolah, guru, dan siswa. Hasil observasi ini menunjukkan bahwa (1) SMK Negeri 2 Depok Sleman memiliki tiga budaya unggulan yaitu budaya disiplin, kerja sama, dan budaya kerja industri, (2) adanya beberapa program penunjang bagi siswa dalam penerapan budaya sekolah, (3) terdapat faktor pendukung dan penghambat terwujudnya budaya organisasi sekolah yang efektif. Menurut hasil observasi, budaya organisasi sekolah di SMK Negeri 2 Depok Sleman sudah dapat dikatakan efektif.
\end{abstract}

Kata kunci: Budaya Organisasi Sekolah, Sumber Daya Manusia Unggul, Efektif 
Sekolah sebagai institusi pendidikan formal, dituntut untuk menghasilkan lulusan yang mempunyai kemampuan akademis tertentu, ketrampilan, sikap dan mental, serta kepribadian lainnya sehingga mereka dapat melanjutkan ke jenjang pendidikan yang lebih tinggi atau bekerja pada lapangan pekerjaan yang membutuhkan keahlian dan ketrampilannya (Moerdiyanto, 2007). Setiap sekolah memiliki tujuan yang tertuang dalam visi dan misi sekolah. Untuk mencapai hal tersebut terdapat lima aspek pokok yang perlu diperhatikan : 1) proses belajar mengajar, 2) kepemimpinan sekolah, 3) manajemen sekolah, 4) sarana dan prasarana dan 5) kultur sekolah (Erfiana, 2008). Namun aspek yang kelima yaitu kultur sekolah, belum banyak diangkat sebagai salah satu aspek yang menentukan upaya peningkatan kualitas dan pencapaian tujuan sekolah. Hasil penelitian mengenai sekolah yang efektif menunjukkan bahwa kultur sekolah atau budaya sekolah merupakan hal yang penting dalam efektivitas sekolah (Gorton \& Snowden, 1991:8).

Sekolah merupakan suatu organisasi, tetapi berbeda dengan organisasi lain terutama organisasi yang berorientasi pada keuntungan. Sekolah merupakan organisasi sosial dan organisasi moral yang mempunyai budaya organisasi yang harus dipahami dan dilibatkan, agar perubahan yang terjadi bisa berlangsung terus menerus dan tujuan sekolah dapat dicapai. Menurut Martin (Kristiawan dkk, 2017), budaya organisasi merupakan serangkaian sikap, nilai, dan keyakinan yang umumnya diciptakan untuk mengarahkan perilaku organisasi. Nilai-nilai dasar yang dianut mengacu pada kode-kode moral, norma, standar, keyakinan, sikap, maksud, kebiasaan dan etika yag menjadi penentu bagi setiap anggota organisasi mengenai apa yang harus dan sebaiknya dilakukan di dalam organisasi

SMK Negeri 2 Depok Sleman merupakan sekolah yang dikenal oleh masyarakat luas sebagai sekolah yang berprestasi baik tingkat provinsi maupun nasional dan juga menghasilkan sumber daya manusia yang unggul, sehingga lulusan sekolah ini banyak diminati oleh dunia industri ataupun dunia usaha. Tentunya hal tersebut didukung oleh beberapa faktor utama seperti sarana dan prasarana yang memadai, kualitas input siswa, kualitas tenaga pendidik, dan budaya organisasi sekolah. Tujuan dari penelitian ini yaitu untuk mendeskripsikan budaya organisasi sekolah yang ada di SMK Negeri 2 Depok Sleman, untuk mengetahui program-program yang dilakukan oleh sekolah dalam mendukung terciptanya budaya organisasi sekolah, serta untuk mengetahui peran budaya organisasi sekolah untuk mencapai tujuan sekolah yaitu menciptakan sumber daya manusia yang unggul.

\section{METODE}

Penelitian ini menggunakan metode penelitian kualitatif yang dilaksanakan di SMK Negeri 2 Depok Sleman mulai tanggal 8 sampai 24 November 2019. Menurut Creswell (dalam Semiawan, 2010) metode penelitian kualitatif merupakan suatau pendekatan untuk mengeksplorasi dan memahami suatu gejala sentral. Definisi lain penelitian kualitatif yaitu suatu pendekatan penelitian yang mengungkap situasi sosial tertentu dengan mendeskripsikan kenyataan secara benar, dibentuk oleh kata-kata berdasarkan teknik pengumpulan data dan analisa data yang relevan yang diperoleh dari situasi yang ilmiah (Komariah \& Satori, 2014). Dapat disimpulkan bahwa, pendekatan kualitatif yaitu sebuah pendekatan tentang suatu kejadian dengan cara mengeksplorasi kejadian tersebut sehingga nantinya dapat disajikan secara deskriptif sesuai kenyataan yang ditemukan. Teknik pengambilan data yang digunakan yaitu wawancara, observasi dan dokumentasi pendukung. Subjek penelitian ini meliputi wakil kepala sekolah, guru, guru BK, dan peserta didik SMK Negeri 2 Depok Sleman. Peneliti berusaha untuk mendeskripsikan kondisi budaya organisasi sekolah di SMK Negeri 2 Depok Sleman dengan mencari informasi secara intensif terhadap informan mengenai budaya sekolah, menganalisis penemuan data di lapangan, dan mendeskripsikan data agar dapat dieksplorisasi.

\section{HASIL}

Menurut hasil wawancara, SMK Negeri 2 Depok dikenal sebagai sekolah yang menghasilkan SDM yang unggul karena lulusan sekolah ini memiliki kompetensi keahlian yang dinilai lebih dari sekolah lain dan yang paling penting adalah karakter siswa/lulusan yang baik dalam dunia kerja. 


\section{Budaya disiplin}

Budaya disiplin dapat tergambar dari tata tertib yang ada di sekolah. SMK Negeri 2 Depok Sleman memiliki tata tertib terkait kedisiplinan diantaranya adalah siswa-siswi wajib hadir di sekolah pukul 06.45 WIB dan kegiatan belajar mengajar dimulai pada pukul 07.00 WIB. Selang waktu tersebut digunakan untuk mengantisipasi siswa agar tidak terlambat, dikarenakan jarak antara parkiran dengan ruang teori yang cukup jauh sehingga membutuhkan waktu lama untuk sampai ke ruang teori. Guru dan karyawan juga diwajibkan hadir di sekolah sebelum jam 07.00 WIB dengan finger print. Mulai pukul 07.00 WIB gerbang selatan sekolah ditutup dan akses masuk sekolah hanya menggunakan gerbang utara. Bagi siswa yang terlambat wajib mengisi form keterlambatan yang telah dijaga oleh gruu piket. Kemudian siswa diarahkan untuk melaksanakan sanksi keterlambatan yang sudah disepakati berupa push up. Bagi siswa yang terlambat wajib mematikan mesin sepeda motor dan wajib mendorong sepeda motornya ke parkiran siswa. Hal ini bertujuan agar siswa tidak lagi datang terlambat ke sekolah, karena akan ada sanksi tambahan di kelas yang diberikan oleh guru yang mengampu mata pelajaran pada jam pertama.

Siswa wajib mengenakan seragam sekolah sesuai dengan ketentuan yang telah ditetapkan sekolah yaitu senin selasa memakai seragam osis, rabu kamis pakaian batik dan jum'at sabtu seragam identitas dan juga siswa dilarang memakai jas lab saat berada di ruang teori arau mata prlajaran non praktikum. Siswa dilarang memakai jaket ketika berada di lingkungan sekolah.

Dari hasil observasi menunjukkan sebagian besar siswa sudah mentaati aturan seragam dan apabila ada siswa yang melanggar, dari pihak guru karyawan maupun siswa yang lain akan menegur siswa tersebut. Tak hanya itu, guru dan karyawan juga wajib mengenakan seragam sesuai dengan ketentuan. Dari hasil observasi ini semua guru sudah memakai seragam sesuai aturan.

Selain tata tertib, SMK Negeri 2 Depok Sleman juga memilki program unggulan yang tergolong baru, yaitu dibentuknya tim stembayo smart. Tim ini terdiri dari beberapa siswa yang menjadi garda terdepan kedisiplinan, yang terdiri dari siswa siswi pilihan dan juga guru pendamping. Beberapa tugas dari tim ini yaitu melaksanakan $5 \mathrm{~S}$ dan juga mengajarkan kepada teman-temannya untuk menerapkan 5S. Setiap pagi ada anggota tim stembayo smart yang menjaga gerbang depan untuk membantu guru piket dalam menertibakan siswa saat memasuki sekolah. Selain itu, setiap hari senin tim ini bertugas menyusuri seluruh tempat di sekolah untuk memastikan bahwa setiap siswa mengikuti upacara bendera dan juga menjaga di barisan belakang saat upacara bendera agar siswa tertib dalam kegiatan upacara.

\section{Budaya kerja sama}

Melalui wawancara, salah satu nilai yang sangat dijunjung oleh warga SMK Negeri 2 Depok Sleman yaitu kerja sama, baik dari siswa, guru, dan juga karyawan sekolah. Contoh penerapan budaya ini, dari hasil pengamatan peneliti adalah kegiatan praktikum siswa yang dilakukan secara berkelompok tentunya menumbuhkan nilai pentingnya kerja sama dalam tim. Selain itu adanya pertemuan rutin kepala sekolah dengan guru dan karyawan untuk membahas sesuatu hal yang penting dalam mencapai tujuan sekolah, menggambarkan adanya kerjasama yang baik antara kepala sekolah dengan guru dan karyawan. Menurut hasil observasi, kerja sama yang terbentuk di lingkungan SMK Negeri 2 Depok Sleman tidak hanya sebatas siswa dengan siswa atau guru dengan guru, namun juga kerjasama antar warga sekolah yang tercermin pada pemanfaatan media sosial WhatsApp (WA), yaitu adanya grup ketua kelas dengan guru, siswa dengan wali kelas, dan juga wali kelas dengan orang tua/wali siswa. Hal itu digunakan untuk menyampaikan informasi dan berkomunikasi, sehingga akan lebih mudah dalam berkerja sama.

\section{Budaya Kerja Industri}

Budaya kerja industri ini termasuk budaya yang menjadikan SMK Negeri 2 Depok Sleman berbeda dengan sekolah pada umumnya. Budaya ini secara khusus dilaksanakan agar siswa nantinya terbiasa dengan dunia kerja yang akan mereka masuki baik ketika melakukan praktik kerja lapangan ataupun ketika sudah bekerja. Hasil penelitian mendapatkan beberapa contoh budaya kerja industri, yaitu (1) adanya jalur hijau di sekolah, yang berfungsi untuk jalur khusus pejalan kaki. Namun, dalam pelaksanaannya masih ada siswa/guru yang berjalan tidak pada jalur hijau karena terbatasnya luas jalan di area sekolah, jalur yang dibuat hanya cukup untuk satu arah. (2) Penerapan Kurikulum 
2013 yang bertujuan untuk melatih siswa agar dapat bekerja secara mandiri, sehingga nantinya siswa mampu menjalankan tugasnya saat PKL (Praktik Kerja Lapangan) atau bekerja, (3) Saat praktikum, siswa wajib melakukan praktikum sesuai SOP (Standar Operasional Pelaksanaan) yang berlaku dan wajib menggunakan jaslab/ wearpack (baju praktik), hal ini bertujuan untuk menjaga keamananan dan keselamatan kerja. (4) Siswa, guru, dan karyawan wajib memarkirkan kendaraannya menghadap ke arah luar, yang tujuannya adalah ketika terjadi suatu bahaya, warga sekolah dapat langsung keluar dari area sekolah dengan mudah. (5) Penerapan slogan budaya 5R (Ringkas, Rapi, Resik, Rawat, Rajin).

Tabel 1 Faktor Pendukung dan Faktor Penghambat

\begin{tabular}{cll}
\hline No & \multicolumn{1}{c}{ Faktor Pendukung } & \multicolumn{1}{c}{ Faktor Penghambat } \\
\hline 1 & Input siswa yang baik & Latar belakang siswa yang berbeda ( keluarga) \\
2 & Tenaga pendidik yang berkompeten & Banyaknya jumlah siswa \\
3 & Banyaknya mitra sekolah & \\
4 & Sarana dan prasaran yang memadahi & \\
\hline
\end{tabular}

\section{PEMBAHASAN}

\section{Budaya Organisasi Sekolah}

Berdasarkan hasil penelitian yang penulis lakukan, dapat diketahui bahwa SMK Negeri 2 Depok memiliki budaya organisasi yang kuat. Hal ini dapat dilihat dari beberapa indikator kuat atau tidaknya suatu budaya organisasi menurut Sathe (dalam Cunningham, 2017) yaitu kekentalan budaya (thickness culture) yang diukur dari tingkat pemahaman seluruh komponen didalamnya, tingkat kebersamaan (extent of sharing) atau keyakinan yang dianut bersama, dan kejelasan dari peraturan. Di SMK Negeri 2 Depok, terdapat tiga budaya yang paling mendominasi dalam budaya organisasi sekolah di sekolah tersebut, yaitu budaya disiplin, budaya kerja sama, dan budaya kerja industri. Nilai-nilai dan normanorma yang terkandung di dalam ketiga budaya tersebut telah diterapkan oleh hampir seluruh warga sekolah dan ketiga budaya tersebut telah tercantum secara jelas dalam tata tertib sekolah. Selain itu, adanya penindakan yang tegas terhadap pelaku pelanggaran peraturan tersebut menggambarkan kejelasan dari peraturan yang ada.

\section{Budaya Organisasi Sekolah Efektif}

Berdasarkan hasil penelitian yang telah penulis lakukan, SMK Negeri 2 Depok telah memiliki budaya organisasi sekolah yang efektif sesuai dengan ciri-ciri budaya organisasi sekolah efektif yang dikemukakan oleh Kristiawan, dkk (2017), antara lain adanya kerja sama, adanya rasa saling percaya, dan adanya transparasi atau sikap keterbukaan. Dalam konteks ciri budaya organisasi sekolah efektif ini, sekolah telah menyediakan kemudahan bagi seluruh warga sekolah untuk mengakses informasi yang berkaitan dengan kegiatan sekolah dan hal yang berhubungan dengan mitra sekolah. Selain itu sekolah juga memiliki kemauan untuk meningkatkan kualitasnya dalam menghadapi tantangan dunia industri melalui program-program seperti workshop atau pelatihan bagi guru dan peningkatan kompetensi siswa melalui ajang perlombaan. Ketiga budaya yang terdapat di SMK Negeri 2 Depok dapat menjadi pondasi utama dalam menciptakan sumber daya manusia yang unggul sesuai dengan tujuan yang tertuang dalam visi SMK Negeri 2 Depok.

\section{SIMPULAN DAN SARAN}

\section{Simpulan}

SMK Negeri 2 Depok memiliki budaya organisasi yang kuat, yang diukur dari tingkat pemahaman seluruh komponen didalamnya, tingkat kebersamaan (extent of sharing) atau keyakinan yang dianut bersama, dan kejelasan dari peraturan. Di SMK Negeri 2 Depok Sleman terdapat 3 budaya organisasi sekolah yang paling mendominasi yaitu budaya disiplin, budaya kerja sama, dan budaya kerja industri. 
Hasil dari penelitian ini menunjukkan bahwa budaya disiplin di SMK Negeri 2 Depok Sleman telah berjalan dengan baik sesuai dengan peraturan yang telah ditetapkan sekolah, baik untuk siswa, guru, maupun karyawan SMK Negeri 2 Depok Sleman. Apabila ada yang melanggarnya, maka warga sekolah yang lain akan langsung memberikan teguran. Begitu pula dengan budaya kerja sama yang sangat dijunjung tinggi oleh warga sekolah. Penerapan kerja sama dilakukan dalam kegiatan pembelajaran dan kerja sama antara guru, karyawan beserta kepala sekolah maupun pihak sekolah dengan orang tua/wali murid. Sekolah membuka seluruh jaringan informasi dan komunikasi dari segala jenis, sehingga antara siswa, guru, dan seluruh warga sekolah menjadi lebih terbuka dan transparan. Hal itu dapat menciptakan kebersamaan dan rasa saling memiliki yang tinggi serta rasa kekeluargaan yang erat.

Budaya organisasi sekolah kerja industri ini termasuk budaya yang menjadikan SMK Negeri 2 Depok Sleman berbeda dengan sekolah pada umumnya. Budaya ini secara khusus dilaksanakan agar siswa nantinya terbiasa dengan dunia kerja yang akan mereka ketika melakukan praktik kerja lapangan atau ketika sudah bekerja. Budaya kerja indutri diterapkan dengan baik agar tercapai lingkungan dan suasana belajar yang kondusif dan menyenangkan serta memberi fasilitas untuk kebutuhan belajar siswa.

Keberhasilan dalam penerapan budaya tersebut juga tidak lepas dari adanya beberapa program kegiatan yang mendukung. Selain itu, cara sekolah dalam menyikapi adanya faktor pendukung dan penghambat juga mempengaruhi keberlangsungan budaya sekolah. Ketiga budaya yang terdapat di SMK Negeri 2 Depok dapat menjadi pondasi utama dalam menciptakan sumber daya manusia yang unggul. Hal tersebut sesuai dengan tujuan yang tertuang dalam visi sekolah sebagai sekolah kejuruan, sehingga dapat membuat SMK N 2 Depok Sleman mejadi sekolah yang memiliki budaya sekolah yang efektif.

\section{Saran}

Sebaiknya setiap sekolah hendaknya memiliki budaya organisasi sekolah yang mampu memberikan efek positif terhadap nama baik sekolah dan semua warga sekolah sehingga dapat menjadikan sekolah yang unggul dan memiliki budaya organisasi efektif sekolah. Karakter peserta didik merupakan hal yang penting dalam upaya pemebentukan dan pengembangan budaya yang baik di sekolah. Oleh karena itu, guru harus mampu mengarahkan peserta didik agar memiliki karakter yang kuat, melalui pembiasaan sikap dan perilaku sesuai dengan nilai dan norma tertentu. Guru juga harus menjadi teladan bagi peserta didiknya. Budaya organisasi sekolah efektif tidak terlepas dari lingkungan keluarga maupun lingkungan masyarakat. Oleh karena itu, sekolah harus menjalin kerja sama dan komunikasi yang baik dengan orang tua siswa maupun dengan lingkungan sekitar sekolah.

\section{DAFTAR RUJUKAN}

Cunningham, I. 2017. The Wisdom of Strategic Learning. Oxfordshire: Taylor \& Francis

Erfiana, A. 2008. Kultur Sekolah Untuk Mengembangkan Good School. Makalah Pengabdian Masyarakat. 1-11

Gorton, R. A., \& Snowden, P.E. 1991. School Leadership and administration. Dubuque, IA: Brown \& Brenchmark. Komariah, A. \& Satori, D. 2014. Metodologi Penelitian Kualitatif. Bandung: Alfabeta

Kristiawan, M. Safitri, D. \& Lestari, R. 2017. Manajemen Pendidikan. Yogyakarta: CV Budi Utama.

Moerdiyanto. 2007. Fungsi Kultur Sekolah Menengah Atas untuk Mengembangkan Karakter Siswa Menuju Generasi Indonesia 2045. Jurnal Konapsi. (7), 4-5.

Semiawan, C. R. 2010. Metode Penelitian Kualitatif. Jakarta: Grasindo. 